Jack Andersen

\title{
Sagen, prosaen - og samfundet: Henimod en samfundsteori om sagprosa
}

\section{Non-fictional Prose and Society: Towards a Social Theory of Non-Fictional Prose}

\author{
Tidsskriftet Sakprosa \\ Bind 13, Nummer 2 \\ (C) 2021
}

10.5617/sakprosa.8095

J. Andersen

$1 / 25$

Sakprosa.no 


\section{Sammendrag}

Denne artikel fremsætter et bud på en samfundsteori om sagprosa. Der er tale om en teori, der fokuserer på sagprosaens medierende effekter og dens indlejring i samfundets virksomhedssfærer. Med dette fokus fremhæves sagprosaens funktion som en konsekvens af samfundets måde at organisere sig på. Artiklen diskuterer først spørgsmålet om, hvordan en sådan teori ser ud.

\section{Abstract}

This article offers a social theory of subject-oriented prose. In doing that, it draws upon and further develops ideas articulated in Swedish and Norwegian research on the matter. The assumption in a social theory of subject-oriented prose is that to understand it, we must understand social structures and the agency of people as it is mediated and constituted by subject-oriented prose. Understanding the latter is understanding its function in society's activity spheres and understanding activity spheres requires understanding the role of subject-oriented prose. This further implies that the notion of 'subjectoriented prose' enacted in the article is concerned with the texts people are producing and reading as part of their doings in the activity spheres they participate in and hence is not limited to the 'mycket lästa' (the much read) by the public. The article's theoretical point of departure is rhetorical genre theory where emphasis is on the action genre accomplishes and on the 'de facto' genres people are engaged with in everyday life and have names for, and hence not genres as defined normatively by scholars.

Nøkkelord: samfundsteori; sagprosa; genreteori

Keywords: social theory; non-fictional prose; genre theory 


\section{Om forfatteren:}

Jack Andersen er lektor ved Institut for Kommunikation ved Københavns universitet. Forskningsinteresser inkluderer sakprosa, sjangerteori og digitale medier. 


\section{Sagen, prosaen - og samfundet: Henimod en samfundsteori om sagprosa}

\section{Prolog}

Sidste efterår var min kæreste og jeg i et byggemarked for at bytte en defekt plæneklipper. Vi havde ikke kvitteringen for købet med. Medarbejderen fandt den i deres informationssystem. Vi fik den printet ud og fik besked på at gå ud til have afdelingen, hvor vi så skulle fremvise kvitteringen. Ude $i$ haveafdelingen kiggede medarbejderen på kvitteringen samtidig med, han slog $i$ op deres system for at tjekke produktet og for at tjekke om det var på lager. Med en notits fik vi besked på, at kunne afhente en ny plæneklipper en af dagene og notitsen skulle medbringes til dette formål. I 'bytte' fik medarbejderen en seddel med vores telefonnummer, så han kunne ringe, når plæneklipperen var kommet hjem til den pågældende butik.

\section{Innledning}

Eksemplet i prologen viser betydningen af sagprosa i hverdagen samt, hvordan sagprosaen er indlejret i samfundets institutioner og strukturer. I Danmark er der en lov, der siger, at mod fremvisning af korrekt kvittering kan en vare byttes omkostningsfrit inden der er gået to år fra købsdato. Denne lov betinger gyldigheden af kvitteringen og dennes evne til at mediere og strukturere enhver interaktion mellem butik og køber, hvis/når sidstnævnte vil bytte en vare. Kvitteringen medfører, at medarbejdere slår op i diverse informationssystemer over fx lagerbeholdning og salg.

Ovennævnte simple byt af en plæneklipper kunne ikke foregå uden interaktion med forskellige tekster. Kvitteringen er teksten, der dokumenterer, at købet er foretaget for mindre end 2 år siden. Informationssystemet havde ydermere 
lagret kvitteringen og dermed sprogligt beskrevet og betinget købet. For medarbejderen i haveafdelingen var kvitteringen et middel til at finde en ny plæneklipper i systemet samt et middel til at udstede en lille notits, der gjorde, at vi kunne afhente en ny plæneklipper en af de kommende dage. Teksterne, samtalerne og informationssystemet både medierede og betingede bytningen. Kvitteringen er selve betingelsen for at kunne bytte samtidig med, den medierer samtalerne kunde og butik imellem. Havde kvitteringen ikke været der, ville der ikke være nogen form for interaktion udover den indledningsvise, hvor man bliver afvist med henvisning til netop en manglende kvittering. Eksemplet kan generaliseres til hele samfundet. Erhvervsliv, forretning, jura, forsikring, økonomi, uddannelse og videnskab består i produktion og cirkulation af tekster og andre symbolske kommunikationsformer. Mennesker involveret på forskellige niveauer i samfundets sfærer er altså specialiserede i at kunne skrive og læse tekster indenfor disse sfærer (Brandt, 2015; Goody, 1986; Smart, 2006).

I nordisk regi er der i både Norge og Sverige, siden 1990’erne pågået rigtig meget værdifuld og vigtig forskning i og om sagprosa. I Norge har dette bl.a. resulteret i en øget sagprosaindsats i folkeskolen og forskningen er blevet institutionaliseret i form af professorater. Man har haft stor succes med at få sagprosaen på den offentlige dagsorden og gjort den synlig som tekst- og litteraturform. Ikke desto mindre forekommer det, at sagprosaforskningen står på et ben. Der er nok et fokus på tekst, kontekst og tekstkulturer, men der synes ikke at være den tilsvarende bevidsthed om betydningen af samfundets strukturende og medierende mekanismer. I denne artikel vil jeg igennem formuleringen af en samfundsteori om sagprosa optegne det forhold, jeg mener, der er er mellem sagprosa og samfundets strukturer. Herigennem forsøger jeg at bidrage til det spørgsmål, Kjell Lars Berge (2001) stillede i sin programmatiske artikel 'Det vitenskabelige studie af sakprosa': "Hva studerer man egentlig når man studerer "sakprosa?” (Berge, 2001, p. 12). Berge argumenterer for en ikke-essentialistisk tilnærming til sagprosaen: 
En ikke-essensialistisk tilnærming vil det innebære at man i første omgang ikke studerer teksters strukturelle egenskaper for å finne ut hva slags tekst man har med å gjøre, men at man tar utgangspunkt i ulike kontekster for tekstskaping, dvs. i de ulike mer eller mindre utviklede kulturkontekstene, institusjonene eller virksomhetene som det skapes tekster av ulike slag i. Istedenfor å finne ut hva det er som gjør at tekster har skjønnlitterære språklige eller tekstlige kvalititeter uavhengig av kontekst - og dermed hvilke tekster som ikke har det, og derfor må kalles "sakprosa" finner vi ut hvor - i hvilke virksomheter - de tekstene som vi i vår kultur kaller "sakprosa”, blir til i, for eksempel i virksomheter som byråkratiet, politikken og den offentlige mening, det religiøse feltet, pressen mm. (Berge, 2001, p. 12).

I denne artikel fortsætter jeg Berges ræsonnement og fokuserer eksplicit på betydningen af tekster og deres samfundsmæssige indlejring - et aspekt jeg anser som værende lidt underspillet. Underspillet i betydningen, at man måske har været lidt for ydmyg omkring den samfundsmæssige indlejring. Nogle af denne artikels pointer og argumenter er derfor måske ikke helt nye for sagprosaforskningen. Det svenske sagprosaforskningsprojekt (Englund \& Ledin, 2003) har således helt klare ligheder med foretagendet i denne artikel. Det nye er måske nærmere det helt eksplicitte forsøg på at formulere en samfundsteori om sagprosa - en form for teori der hidtil ikke har været fremsat i sagprosaforskningen. Der er tale om en teori, der ikke kan eller skal verificeres eller falsificeres. Som enhver anden fornuftig fortolkende teori, er den et redskab til at tænke med og til at give ét bestemt blik på et fænomen

Så selvom jeg måske peger på noget åbenlyst omkring sagprosaens samfundsmæssige indlejring, er det i lyset af lige netop denne indlejring ikke desto mindre vigtigt, at inddrage perspektiver fra samfundsteorien, der leverer begreber til at sætte forholdet mellem aktører, strukturer og 
menneskelig handling på dagsordenen. Den retoriske genreteori sætter lige præcis dette forhold på dagsordenen. Derfor er mit argument bygget op omkring dén antagelse, at genreteorien er et uomgængeligt element i en samfundsteori om sagprosa og dennes samfundsmæssige funktion. Mit udgangspunkt til argumentet i denne artikel tages altså i genreteorien for herfra, at kunne forstå og beskrive sagprosaens samfundsmæssige indlejring. Dette står i modsætning til andre studier af sagprosa, hvor udgangspunktet typisk har været konkrete tekster, forfattere eller organisationer og herudfra vise sagprosaens samfundsmæssige funktion (fx Kjærgaard, 2012; Nyström Höög, Söderlundh \& Sörlin, 2012).

Det følgende argument er tænkt opbyggeligt. Jeg starter med at se på sagprosa-begrebet og hvor jeg stiller mig i denne diskussion. Herefter vender jeg blikket mod den retoriske genreteori, fordi den netop har fokus på forholdet mellem menneskelige aktører, sociale strukturer og tekster som medierende led heri. Dernæst diskuterer jeg, hvordan en samfundsteori om sagprosa kan se ud og hvad den skal kunne.

\section{Sagprosa-begrebet}

I forbindelse med diskussioner af sagprosabegrebet bliver det tit fremhævet, at det er et særegent nordisk begreb. Jeg vil derfor starte med at se på, hvad de to norske sagprosaforskere Johan Tønnesson og Kjell Lars Berge har skrevet om begrebet samt, hvordan sagprosa udlægges i det svenske sagprosaprojekt (Englund \& Ledin, 2003). Fælles for disse er, at de helt eksplicit afstår fra at essens-definere begrebet. Jeg er helt enig heri. For det første, fordi essensdefinitioner er ahistoriske. Det giver ikke mening at operere med et sådant, når man har at gøre med historiske størrelser som tekster produceret og brugt i tid og rum. For det andet, så er essens-definitioner utrolig ufrugtbare at tænke med, fordi den første operation altid bliver, om det man studerer nu passer ind i definitionen. Et sådant Sisyfos-arbejde flytter ikke erkendelsen. 
Jeg vil tilslutte mig Tønnessons pragmatiske udlægning af sagprosa:

"Sakprosa er i vid forstand tekster som mottakeren har grunn til å oppfatte som direkte ytringer om virkeligheten” (Tønnesson, 2008, p. 34). Denne pragmatiske tilgang til sagprosabegrebet er fornuftig lige præcis, fordi den lægger vægt på, at vi som modtagere af sagprosa-tekster er begrundet i at opfatte disse som ytringer om virkeligheden. De er ikke virkeligheden. De er ikke en platonisk afspejling af virkeligheden. Der er ikke tale om et korrespondensteoretisk forhold til sandhed og virkelighed, men nærmere et kohærensforhold, hvis vi skal tale i epistemologiske termer. Busplanen der angiver rute, busnummer og tidspunkter for afgang og ankomst er en ytring om virkeligheden, vi som brugere af busser kan være begrundet i at stole på og agere efter - også selvom der kan være forsinkelser og aflysninger.

Men hvad Tønnesson ikke dækker med sin definition, er, at sagprosa ikke kun er direkte ytringer om virkeligheden. Sagprosa skaber virkeligheder og bliver skabt af virkeligheder. Når jeg for eksempel skal skrive en forskningsansøgning om midler til et projekt, da er der flere sæt af tekster, jeg som ansøger skal forholde mig til. Alt lige fra de mere administrative lag som $\mathrm{fx}$ fondens tekster, økonomiberegninger fra mit universitet og ikke mindst det videnskabelig felt og dets tekster, jeg skriver mig ind i og op imod. Jeg kan ikke ønske alle disse lag og sæt af tekster væk, hvis jeg vil have et håb om succes med ansøgningen. Samtidig skaber jeg en konkret virkelighed med min ansøgning, som andre ikke kan ønske bort, men skal tage stilling til. Dette dialektiske aspekt er vigtig at have med, fordi det viser sagprosaens strukturende effekter. Vi kan også sige, at der er tale om sagprosaens dobbelte hermeneutik.

Kjell Lars Berge (2001) afstår ligeledes fra at definere sagprosa strengt videnskabeligt. Berge taler i stedet for sagprosa som "en slags anviser som peker i retning av en tekstforskning der andre tekster studeres enn dem vi i vår tekstkultur for tida av ulike grunner forstår som skjønnlitterære” (Berge, 
2001, p. 18). Til forskel fra Tønnesson, fokuserer Berge altså sagprosa som en anviser i det felt af tekster, der ikke er skønlitterære, og dermed bruger han skønlitteraturen en slags umiddelbar antitese til sagprosaen. Men som Berge helt rigtigt anfører, så giver en sådan 'avslappet holdning' til begrebet netop mening, fordi den åbner op for at kunne studere sagprosaen samtidigt og historisk, dvs i tider og kulturer hvor den moderne skelnen mellem sagprosa og skønlitteratur ikke findes eller giver mening (Berge, 2001, p. 19). Selvom Berges indkredsning er løs, er den meningsfuld, fordi den tilbyder et blik, hvormed vi kan indkredse tekster, der ikke forstår sig selv og forstås af andre som skønlitterære.

Ideen om sagprosa som en slags vejviser findes også formuleret i det svenske sagprosaprojekt. Englund, Ledin \& Svensson (2003) skriver fx herom, at de ønsker som en modvægt til en essentialistisk opfattelse at opfatte sagprosa som et social faktum: ”... dvs, som en kategorisering som har uppstått i en viss historisk epok och som styr vår uppfattning av samhällets textverklighet” (Englund, Ledin \& Svensson, 2003, p. 36). Ønsket om at forstå sagprosa som et socialt faktum er med til at fastholde sagprosa som et konkret oplevet kommunikationsfænomen. Sagprosa som et socialt faktum er yderligere med til at understrege sagprosaen som vejviser i en tekstvirkelighed, der ikke er skønlitterær: "Snarare blir det en sorts kompass som pekar mot texter som av olika anledningar inte anses vara skönlitterära och mot olika textkulturer" (Englund, Ledin \& Svensson (2003, p. 36). Denne vejviser funktion er altså med til at tjene som et blik på de tekster, der ikke er skønlitterære, men som har konkrete funktioner i samfundet.

Jeg læner mig i det følgende op ad både Tønnessons, Berges og Englund, Ledin \& Svenssons (2003) pragmatiske udlægninger af sagprosa, fordi ligegyldigt om sagprosa som begreb måske er upræcist, så har vi ikke desto mindre at gøre med en bunke af tekster i samfundet, der udfører et specifikt type arbejde i de sociale felter og tekstkulturer, hvori de er en central del. For 
aktørerne i disse felter og kulturer er disse tekster reelt forekommende og ikke-fiktive. Det er nyttigt at fokusere på sagprosa som ytringer om virkeligheden og som socialt faktum, man som læser er begrundet $i$ at tro, handler om virkeligheden, fordi dette er med til at fastholde sagprosatekster som tekster om en sag og en sag der vil noget. Rent metodologisk kan vi derfor også sige med Berges og Englund, Ledin \& Svenssons ord, at sagprosa er en slags rettesnor i en forskning af sag og prosa, der ikke kan henføres til skønlitteratur. En specificering af en sådan rettesnor kan findes i den retoriske genreteori.

\section{Det retoriske genrebegreb}

Siden Carolyn Miller begrebsliggjorde genre som en social handling (Miller, 1984), har dette genrebegreb stået stærkt, når vi skal forstå og beskrive tekstligt medierede og betingede strukturer (Smith, 1974; Bazerman, 1988, 1994, 1997; Bazerman \& Russell, 2003; Yates, 1989; Russell, 1997; Winsor, 1999, Schryer, 1993; Freedman \& Medway, 1994; Geisler, 2001; Devitt, 2004; Luckmann, 2009; Starke-Meyerring et al., 2011; Reiff \& Bawarshi, 2016). Ved at flytte fokus i genreforståelsen væk fra form og klassifikation samt væk fra de klassiske retoriske genrer og henimod den gentagne og regelmæssige/ typificerende brug af tekster (og ytringer) i tilbagevendende hverdagssituationer, 'de facto' genrerne, som Miller (1984) kalder dem, har genreforskningen tegnet en bane op, hvor det samfundsmæssige aspekt af tekster og deres sociale indlejring bliver skærpet. I en samfundsteori om sagprosa er genre derfor helt centralt. Det er for det første centralt, fordi det har fokus på 'de facto' genrer; altså de genrer som brugerne definerer og arbejder med i hverdagen og ikke dem som vi analytisk opfinder i forskningen. For det andet, så leverer genreteorien et sæt af begreber, der netop er udviklet til at forstå forholdet mellem social struktur, tekster og menneskelig handling ( $\mathrm{fx}$ genresæt, genre- og virksomhedssystemer, genrerepertoire). For det tredje, genre som social handling indbyder til det helt eksplicitte fokus på handling 
og funktion, fremfor form og indhold, og dermed, hvad tekster er i stand til at gøre i skriftlig kommunikation.

Genreteorien tilbyder sig altså som en væsentlig byggesten i udformningen af en samfundsteori om sagprosa. Med dens betoning af gentagne og typificerende handlinger med tekster i tilbagevendende situationer, peger genreteorien på, hvordan individer og grupper i et samfund lærer at handle med sproget. Med genreteorien lærer vi at genkende situationer, der kræver vores kommunikative handlinger samt at have socialt udformede forventninger til givne kommunikative handlinger. Forbindelsen mellem genreteorien og en samfundsteori om sagprosa kommer dermed til syne, når førstnævnte påpeger, at vi som kommunikerende individer og grupper altid befinder os i situationer, hvis typificering angiver, hvilke kommunikative handlinger der kan/bør laves i situationen. Selve typificerings-aspektet, som Miller (1984) selv henter i den fænomenologiske sociologi (Schütz, Luckmann), er med til at understrege sagprosaens samfundsmæssige indlejring, men også dens samfundsskabende karakter: mennesker gør noget igennem og ved hjælp af sagprosa i konkrete situationer, der igennem sine egne historisk udviklede strukturer sætter rammer op for sagprosaens funktion, men også for menneskers muligheder for at genkende specifikke situationer, der kræver deres kommunikative handlinger. Vores genreviden er en viden om samfundet og de indlejrede kommunikations-kontekster med deres specifikke typer af tekster, der kalder på individers og gruppers kommunikative handlinger (Berkenkotter \& Huckin, 1993).

Udover det vigtige fokus på 'de facto' genrer (hverdagsgenrer), leverer genreteorien altså det sæt af begreber hentet fra samfundsteorien, der muliggør at tænke i retning af forholdet mellem sagprosa, sociale strukturer og menneskelige aktører. 


\section{Henimod en samfundsteori om sagprosa}

I den nordiske sagprosaforskning findes der ikke eksplicitte forsøg på at formulere en samfundsteori om sagprosa. Der findes rigtignok bidrag, der kunne pege i denne retning som fx Ledin \& Selander (2003). Deres hensigt er at pege på, hvordan begreber som institution, tekst og genre er med til at gøre sagprosa til en grundlæggende del af det sociale liv (Ledin \& Selander, 2003, p. 91). Jeg er helt enig med Ledin \& Selander i denne påpegning, men i denne artikel tager jeg skridtet videre i teoriformuleringen.

Men hvorfor, må man allerførst spørge, skal vi have en samfundsteori om sagprosa? Hvad skal den kunne gøre? Hvad udsiger den noget om? Hvad gør den os i stand til at forstå? En samfundsteori om sagprosa skal hjælpe os til at forstå og beskrive samfundet og dets samtidige og historiske udvikling igennem sagprosaen og dens genrer. Men, kan vi spørge, hvad er det, vi forstår her, når vi forstår samfundet og dets samtidige og historiske udvikling igennem sagprosaen og dens genrer? Det er en måde at forstå de tekster, der historisk og nutidigt har gjort og gør et kommunikativt-epistemologisk arbejde i samfundets store sfærer som fx økonomi, erhverv, jura, uddannelse, videnskab, medicin eller arbejdslivet generelt. Der er tale om de tekster, som samfundet og dets institutioner og aktører gør brug af for at få deres konkrete og lokale praksisser til at fungere i hverdagen. Det vil sige tekster, som offentlige institutioner og myndigheder, private virksomheder og frivillige organisationer producerer og gør brug af i deres samfundsmæssige virke. Der er tale om formålsrettede tekster med sagen i fokus: tekster der skal krydstjekkes, formularer der skal udfyldes, fyldes tekst ind i specifikke felter, søges efter, læses og skrives med henblik på forståelse og handling osv. Ligeledes er de tekster og ytringer (tweets, hashtags, onlinekommentarer, blogs) mennesker producerer i hverdagen som led i deres kommunikative aktiviteter at regne med her, fordi de fænomenologisk set må betragtes som kommunikative handlinger, som et socialt faktum, hvormed mennesker 
tilskriver mening til deres livsverden. Der er altså mest fokus på det, Tønnesson (2009, 2013) kalder for den funktionelle sagprosa, men også den litterære sagprosa, eftersom fx videnskabelige tekster lige præcis er tekster, forskere gør brug af i deres konkrete arbejde. Men i stedet for at operere med en inddeling i funktionel og litterær sagprosa, vil jeg foreslå, man tager udgangspunkt i mennesket og dets sociale og kommunikative behov: dvs den sagprosa og dens genrer der omgiver og betinger mennesket som privat person, lønmodtager eller borger. Menneskets 'de facto genrer' kort sagt. Som påpeget af Miller (1984) er det ikke frugtbart at operere med a priori kategorier af tekster (som fx funktionel og litterær sagprosa), fordi sådanne ikke fortæller os noget om de utallige kommunikative praksisser og situationer, et menneske befinder sig i. Kategoriseringerne bliver i stedet for uhensigtsmæssigt normative og formuleret fra en forsker/kritikerposition og ikke fra en brugsposition. Selve brugen har naturligvis forskellig karakter alt efter, om vi taler om privatpersonen, lønmodtageren eller borgeren. Fx adskiller 'Coffee table books' eller biografier sig brugsmæssigt fra notater, bestillinger eller brugsanvisninger, man måtte gøre brug af på sit arbejde.

Under alle omstændigheder bliver der dog tale om en prosa med en sag, der gør noget. Som Tønnesson \& Berge (2009, p. 8) skriver, så beskæftiger sagprosaforskningen sig grundlæggende forholdet mellem tekst og sag: '... i det store universet som omfatter det meste af det som skrives utenfor det som vi til enhver tid i vårt samfunn opfatter som tekster tilhørende den skjønlitterære institutionen' (Tønnesson \& Berge, 2009, p. 8). Denne iagttagelse er vigtig, fordi den sætter fokus på de tekster, der cirkulerer uden for den skønlitterære institution. Dette store univers er samfundets virksomhedssfærer og deres tekster; forholdet mellem tekst og sag, mellem tekst og kontekst. En samfundsteori om sagprosa starter lige her.

Én konsekvens af Tønnesson \& Berges iagttagelse, er, at vi kan begynde at se på sagprosaen som indlejret i samfundets institutioner og kommunikative 
praksisser. Sagprosa medierer mellem den sociale organisering af viden $i$ samfundet og de individuelle aktørers hverdagshandlinger. Dette betyder bl.a., at sagprosaen og dens genrer står i et direkte forhold til de institutioner og praksisser, hvori sagprosaen har en funktion. Sagprosaen er så at sige infiltreret i samfundet. En samfundsteori herom skal på en og samme tid vikle sagprosaen ud af samfundet for at få den til at fremstå mere klart som tekstog litteraturkategori, der ikke bare er en vejviser i det korpus af tekster, der befinder sig udenfor den skønlitterære institution. Samtidig skal den fastholde blikket på sagprosaens samfundsmæssige indlejring, fordi den ikke skal fremstå som løsrevet fra de menneskelige virksomhedssfærer og som en ahistorisk tekst- og litteraturform. En samfundsteori om sagprosa skal altså forsøge at beskrive dette forhold mellem samfundets institutioner, den sociale organisering af viden igennem sagprosaen og de enkelte aktørers handlinger heri.

Sociale strukturer både betinger og er resultatet af aktørers handlinger (Berger \& Luckmann, 1972; Giddens, 1984). Denne dialektik er så fundamental for alle menneskelige virksomhedssfærer. Den er derfor nyttig, når man skal tænke sagprosaen ind i samfundets strukturer, men har måske været fraværende i sagprosaforskningen (med undtagelse af fx Ledin \& Selander, 2003). Omvendt kan man heller ikke sige, at sagprosaforskningen ikke beskæftiger sig med tekster i samfundet. Sagprosaforskningen er generelt meget bevidst om betydningen af tekst og kontekst (Tønnesson, 2008; Berge, 2001; Englund \& Ledin, 2003). Men sagprosaforskningen har måske helt undladt at stille det helt grundlæggende spørgsmål: hvordan forstår vi et samfund og dets tekstkulturer igennem sagprosaens briller? Hvad er det, vi ser? Hvad siger sagprosaen om samfundet? For eksempel, hvad fortæller det om et samfund, når evalueringer, dokumentation, årsrapporter og måltal i stigende grad bliver uomgængelige genrer i skolen såvel som i det øvrige samfund (se fx Höög \& Kvåle, 2018)? Hvorfor har man ordbøger? Hvorfor har man leksika? Hvad gør huslejekontrakter? Hvorfor gør man brug af rapporter, 
notater og mødereferater? Hvorfor kommunikerer staten til borgerne igennem kampagner, foldere, pjecer eller websteder som fx Borger.dk i Danmark eller Norge.no i Norge? Eller når tags, blogindlæg og tweets bliver brugt som sociale og kommunikative handlinger i hverdagen? Svarene på disse spørgsmål vil pege i retning af, at eksistensen og fremkomsten af visse former for tekster på specifikke historiske tidspunkter fortæller os noget om samfundet. Men fokus bliver flyttet fra de specifikke tekster og deres handlinger og over til at forstå, hvordan forskellige sfærer i samfundet rent faktisk fungerer historisk, socialt og kommunikativt på grund af sagprosa. En samfundsteori om sagprosa kan derfor ikke kun have fokus på 'det mycket lästa' (Englund \& Ledin, 2003, p. 18). Den må være mere generisk og have fokus på det, der vitterlig bliver skrevet, læst og brugt i samfundets sfærer og af mennesket som privatperson, lønmodtager eller borger.

Berger \& Luckmann (1972) argumenterer i deres videnssociologi om vigtigheden af, at få øje på den viden, der 'er stivnet i hverdagen'; dvs den viden der så at sige er blevet infrastrukturel. Ligeledes med sagprosaen. Det er vigtigt at 'afstive' sagprosaen, fordi vi herved får mulighed for at udforske den nærmere og stille nogle spørgsmålstegn til den og med den. Men vi kan ikke at tage den ud af rammen for at stå med den 'rene' sagprosa i hånden; at løsrive tekst fra kontekst. Vi kan aldrig undslippe sagprosaens tekstkulturer (Berge, 2001; Tønnesson, 2008) eller de menneskelige virksomhedssfærer (Russell, 1997; Winsor, 1999; Bazerman, 1997; 2013), fordi de betinger, og er betinget af, sagprosa. Yderligere er det forskningsmæssigt også et problem, hvis sagprosaen er 'stivnet i hverdagen' (jf Berger \& Luckmann, 1972), fordi ved at tage sagprosaen for givet overser vi samtidig en væsentlig tekst- og kommunikationsform i samfundet med stor indflydelse på, hvordan samfundets forskellige sfærer arbejder, fungerer og kommunikerer. Stort set al sagprosaforskning peger derfor på, at sagprosaen er et funktionelt og pragmatisk anliggende. Sagprosaen er sat i verden for at udrette noget på vegne af nogen med henblik på at opnå en vis effekt i kommunikationen hos 
nogle andre. Dette forhold er med til at understrege sagprosaens funktionelle indlejring i en større social sammenhæng. Den både medierer og betinger, og bliver betinget af, andre aktørers og sfærers intentioner, motiver og handlinger.

Ved at insistere på at en teori om sagprosa også er en teori om samfundet, har man flyttet fokus fra kun at være sagprosaens retorik, form og indhold til dens funktionelle indlejring i samfundets sfærer. Med funktionel indlejring mener jeg sagprosaens kommunikative og epistemologiske funktion i forskellige sociale og menneskelige virksomheder. Enhver virksomhedssfære er et led i samfundets arbejdsdeling og til at udfylde denne funktion gøres der brug af sagprosa. En samfundsteori om sagprosa har fokus på dette forhold, at samfundets sfærer udgøres af sagprosa og at sagprosaen opstår af samfundsmæssige behov. Dermed bliver én måde at forstå et samfund på også lig med at se på dets produktion og brug af sagprosa som en del af et magtapparat (se fx Berge, Meyer \& Trippestad, 2003).

Derfor kan en samfundsteori om sagprosa, som der argumenteres for her, være nyttig for sagprosaforskningen og samfundsforskningen. Den er med til at sætte fokus på sagprosaens samfundsmæssige funktion og den er et middel til at diagnosticere samfundet igennem sagprosaens briller. En lignende betragtning er blevet fremsat af Dorothy Smith for over 30 år siden. Smith var optaget af at gøre tekster (fx pas, regninger, recepter, jobansøgninger) i samfundet synlige som et sociologisk fænomen med et perspektiv, der tydeliggør "... documents as constituents of a social course of action in which they are first produced and then become active in the ordering of subsequent phases and the relations among them" (Smith, 1984, p. 70). Smith pegede herigennem på sagprosaens kritiske potentiale i og med, at enhver samfundteori må være diagnosticerende i form af strukturelle analyser og magtanalyser. Sagprosaen er et konkret og vigtigt sted som begyndelse for 
sådanne analyser, som anskueliggjort af fx både Foucault (1972) og Fairclough (1992), om end ingen af sidstnævnte eksplicit gør brug af et sagprosabegreb.

En samfundsteori om sagprosa interesser sig altså for, hvordan samfundet og dets institutioner og sfærer kommunikerer igennem, og er betinget af, sagprosa. Den er derfor et postulat om, at sagprosaen på én og samme tid er et produkt af og en kommunikativ respons på samfundets måde at organisere sig på i form af dialektikken mellem sociale strukturer og de konkrete menneskelige handlinger og ytringer (Giddens, 1984; Fairclough, 1992). Sagprosa er derfor både en subjektiv og objektiv realitet (Berger \& Luckmann, 1972).

Når sagprosaen er et socialt faktum (Englund, Ledin \& Svensson, 2003, p. 36), er en samfundsteori om sagprosa dermed med til at fastholde blikket på sagprosa som samfundsskabt fænomen og et konkret oplevet fænomen for borgeren, lønmodtageren, privatmennesket eller 'brugeren'. Det er blikket, det handler om. Man kunne også forankre en teori om sagprosa i kulturteori, tekstteori, litteraturteori, medieteori, antropologisk teori osv. Hver for sig ville sådanne teorier være et udtryk for et specifikt blik på sagprosaen og ville som konsekvens skabe sagprosaen som analytisk og empirisk objekt. Det er der ikke noget galt i. En samfundsteori om sagprosa har netop også at gøre med blikket og hvordan dette blik skaber sagprosaen som analytisk og empirisk objekt: At insistere på at sagprosaen er et vigtigt samfundsfænomen i og med, den fænomenlogisk findes 'derude', er et socialt faktum, og at den materialiserer sig i mange forskellige genrer og situationer og at sagprosaen dermed har betydning for menneskers hverdagsliv; at blikket på en og samme tid kommer fra sagprosaen og samfundet. Sagprosaen er som sagt funktionsbestemt og indtager en plads i samfundets kommunikative og epistemologiske arbejdsdeling (Andersen, 2002). Vi er omgivet af sagprosa. Vi kan ikke undslippe den i mange af vores daglige kommunikative interaktioner. Når man skal ansøge om lån i banken og kreditforeningen med henblik på 
boligkøb skal man læse tekster om lånebetingelser og man ender måske med at skrive under på en købsaftale. Som ejer af en bolig er man dermed konstitueret af de forskellige sagprosagenrer, der gør en til boligejer: forsikringer, lånebevis, låneaftale, skat. Når journalister i aviser, tv og radio refererer til rapporter, undersøgelser og beretninger ('ifølge rapporten...', 'undersøgelser viser at..., ’i beretningen kan man læse at...') som led i journalistiske indslag gøres der brug af specifikke sagprosagenrer produceret med henblik på bestemte formål i en bestemt sammenhæng. Når børn i folkeskolen skal lære at argumentere lærer de at producere sagprosaytringer, ytringer om virkeligheden (Tønnesson, 2013).

Eksistensen af sagprosaen i samfundet er et produkt af bevidste menneskelige valg og samfundsmæssige behov. Valg og behov der ikke i første omgang tager højde for kommunikationens sanselige og æstetiske sider, som skønlitteraturen bl.a. gør og skal. I sin form og funktion skal skønlitteraturen netop tilbyde os sanselige og æstetiske sider af den kunstneriske kommunikation. Vi bør ikke underlægge sagprosaen dette krav som det eneste. Af den simple grund at det kan og skal den ikke honorere. En huslejekontrakts betydning bliver ikke bestemt af dens sanselige og æstetiske udformning, men af dens retoriske formål; mere præcist, hvilke juridiske rettigheder og ansvar, der påhviler henholdsvis udlejer og lejer af en bolig; hvilke handlinger den kan pålægge eller pålægger den enkelte aktør. En huslejekontrakt er ikke et stykke fiktion, vi kan fortolke, nyde og bruge, som vi vil. Hvis vi gør, slår virkeligheden tilbage; hvis udlejer fx ikke betaler leje og ikke mener, at det skal vedkommende, fordi sådan læser vedkommende ikke kontrakten, vil udlejer med juraens hjælp (sandsynligvis) få lejeren sat ud af lejligheden. Huslejekontrakten er med dette indlejret i samfundet, fordi dens sprog og dens gøren er juraens, retorikkens og økonomiens. Ligeledes med fx Brexit. Storbritannien kan ikke træde ud af EU uden, der er nedfældet en tekst, der begrunder, certificerer, klargør og meddeler om udtrædelsen. Sagt på en anden måde: en storpolitisk handling som en udmelding af EU er, kan 
ikke finde sted og vil ikke kunne iagttages uden udformningen af en tekst (eller flere tekster), der betinger, medierer og beskriver denne handling.

Som producenter og brugere af sagprosa er vi kommunikativt og epistemologisk forpligtet overfor den og betinget af den i forskellige kommunikative handlinger. Sagprosaen og dens konkrete genrer og deres samfundsmæssige indlejring slår så at sige tilbage. Fænomenologisk formuleret kan vi sige, at sagprosaen i sin konkrete og lokale anvendelsessituation nok er underlagt specifikke subjekters gøren med den ligesom sagprosaen også bestemmer, hvad der kan gøres med den. Samtidig er de konkrete og lokale anvendelsessituationer sociale og historiske fænomener betinget af andre hidtidige subjekters konkrete valg og gøren, der går forud og dermed er med til at forme den konkrete og lokale nutidige anvendelse af enhver form for sagprosa. Fx viser Ditlevsen (2012), hvordan Danisco’s årsrapporter som genre over tid er blevet mere sprogligt og retorisk komplicerede på grund af, at de skal legitimere sig overfor flere og til tider modsatrettede interessenter. Årsrapporten som genre i dag er dermed et produkt af sociale og historiske omstændigheder, der går forud for dens konkrete brugssituation, men som virker tilbage på den (Skärlund, 2020). Sagprosaen og dens indlejring i samfundet er altså et udtryk for, hvordan den bliver tilegnet i konkrete, samtidige, subjektive og lokale situationer, samtidig med, den er i verden som en objektiv realitet i kraft af dens konkrete institutionelle, formmæssige og genremæssige manifestation.

\section{Afsluttende bemærkninger}

Sagprosaen tilhører samfundet og er som sådan betinget af både materielle og kommunikative samfundsforhold. Som fænomenologisk fænomen er sagprosaen indlejret i samfundet og har kun værdi heri i kraft af menneskers og institutioners brug af sagprosa. Ingen brug, ingen sagprosa. Som analytisk og teoretisk fænomen er sagprosaen en særskilt tekst- og litteraturkategori, 
der både har egne normer og til tider deler normer med fiktionslitteraturen. En karakteristisk og afgørende norm for sagprosaen er forpligtigelsen på virkeligheden. I og med, sagprosa er et produkt af menneskers sociale og kommunikative praksisser, er den også forpligtet af disse praksisser, fordi sagprosaen netop er med til at vedligeholde, stabilisere og mobilisere praksisser igennem menneskelig virksomhed. Ved at insistere på sagprosaens funktion og indlejring i samfundsmæssige kontekster som fx i erhverv, forsikring, videnskab, jura, uddannelse eller økonomi, slipper man dermed også for at definere den negativt i forhold til fiktionslitteraturen, fordi blikket $\mathrm{i}$ stedet rettes mod de kontekster og situationer, der bruger specifikke typer af tekster regelmæssigt og på tilbagevende vis. Herigennem opdager man tekster, der har navne som fx afrapporteringer, evalueringer, regnskaber, kontrakter, mødereferater, årsrapporter, bekendtgørelser, love, notater, videnskabelige artikler, call-for-papers, skemaer, lærebøger etc. - alle eksempler på tekster, der er forpligtet på en virkelighed, har en funktion og gør et arbejde.

Sagprosaens funktionelle indlejring i kommunikative og epistemologiske funktioner i forskellige sociale og menneskelige virksomheder har nogle implikationer. Som følge af bl.a. den retoriske genreteori og dens fokus på genrer i hverdagen, da er de klassiske retoriske genrer nærmest uinteressante i samfundsteori om sagprosa. Hvad fortæller den politiske, juridiske eller lejlighedstalen om samfundets tekstligt medierede strukturer og menneskers handlinger med tekster i hverdagen? Nærmest intet! Selvfølgelig giver det mening at studere taler med henblik på deres funktion, form og indhold og hvilke forventninger til og muligheder for genkendelse af taler. Men det giver ikke mening, hvis man vil have et fokus på de tekster i samfundet, der gør et konkret stykke i arbejde i konkrete menneskelige virksomheder med sine rutiner og typificeringer. En seriøs og samfundsrelevant sagprosaforskning må tage udgangspunkt lige her. Et fokus på taler er i store træk et fokus på personen bag, talen og dens effekt. Det er et begrænset fokus, fordi det 
overskygger alle de dunkle og trivielle, men ikke desto mindre yderst vigtige tekster i samfundet, vi som borgere, lønmodtagere og privatmennesker omgives af, er afhængig af og i mange situationer betinget af (jf Miller, 1984). Disse former for tekster og deres tilknyttede sociale interaktionsformer er vigtige for os at forstå, fordi de er med til at fortælle noget om, hvordan samfundet organiserer sig igennem skriftlig kommunikation. Når Berge (2001) derfor spørger, hvad det er, man studerer, når man studerer sagprosa, er mit bud på et svar, at man studerer forholdet mellem de forholdsvist strukturerede menneskelige virksomhedssfærer og deres tilknyttede tekster og aktører. Og videre, når man skal lære at forstå og fortolke sagprosaens indhold, form og funktion, da kommer dette bl.a. til udtryk ved, at kunne navigere i samfundets tekstuelt medierede strukturer og kunne genkende situationer og sammenhænge, der kalder på specifikke kommunikative handlinger.

Vigtigheden af at insistere på sagprosaens selvstændige form kommer altså af, at det er nødvendigt i det omfang, man bruger sagprosaen til at sige noget om samfundet $o g$ samfundet til at sige noget sagprosaen. 


\section{Litteratur:}

Andersen, J. (2002). The role of subject literature in scholarly communication: an interpretation based on social epistemology. Journal of Documentation, 58(4), 463-481.

Bazerman, C. (1988). Shaping Written Knowledge: The Genre and Activity of the Experimental Article in Science. Madison, USA: University of Wisconsin Press.

Bazerman, C. (1994). Systems of genres and the enactment of social intentions. I A. Freadman \& P. Medway (red.), Genre and the new rhetoric. Taylor \& Francis. 79-101.

Bazerman, C. (1997). Discursively structured activities. Mind, Culture, and Activity, 4(4), 296-308.

Bazerman, C. \& Russell, D. R. (2003)(Eds). Writing Selves/Writing Societies: Research from Activity Perspectives. Perspectives on Writing. The WAC Clearinghouse; Mind, Culture, and Activity.

(https://wac.colostate.edu/books/perspectives/selves-societies/)

Berge, K. L. (2001). Det vitenskapelige studiet av sakprosa. Om tekstvitenskapelige utfordringer og løsninger i norsk og svensk sakprosaforskning. I: Sakprosa-skrifter fra prosjektmiljøet Norsk sakprosa.

Berge, K. L., Meyer \& Trippestad, T. A. (2003) (red.). Maktens tekster. Oslo: Gyldendal Akademisk.

Berge, K. L. (2019). Skriftkulturforsking i Norden. Nokre overordna perspektiv på forskingsfeltet og forskingsresultat på 2000-talet. I: Stig Jarle Helset \& Endre Brunstad (red.), Skriftkulturstudiar i ei brytingstid. Oslo: Cappelen Damm Akademisk. 21-52.

Berger, P. L. \& Luckmann, T. (1972). Den samfundsskabte virkelighed: En videnssociologisk afhandling. Lindhardt \& Ringhof.

Berkenkotter, C. \& Huckin, T. N. (1993). Rethinking Genre from a Sociocognitive Perspective. Written Communication, 1O(4), 475-509. 
Brandt, D. (2015). The Rise of Writing: Redefining Mass Literacy. Cambridge: Cambridge University Press.

Devitt, A. (2004). Writing Genres. Illinois: Southern Illinois University Press.

Ditlevsen, M. G. (2012). Telling the Story of Danisco's Annual Reports (1935 Through 2007-2008) From a Communicative Perspective. Journal of Business and Technical Communication, 26(1), 92-115.

Englund, B. og Ledin, P. (red.) (2003). Teoretiska perspektiv på sakprosa. Lund: Studentlitteratur.

Englund, B. Ledin, P. \& Svensson, J. (2003). Sakprosa - vad ër det? I: Englund, B. og Ledin, P. (red.). Teoretiska perspektiv på sakprosa, 3559. Lund: Studentlitteratur.

Fairclough, N. (1992). Discourse and Social Change. Cambridge: Polity Press.

Foucault, M. (1972). The Archeology of Knowledge \& The Discourse on Language. Tavistock Publications.

Freedman, A. \& Medway, P. (red.). Genre and the New Rhetoric. London: Taylor \& Francis.

Geisler, C. (2001). Textual Objects: Accounting for the Role of Texts in the Everyday Life of Complex Organizations. Written Communication, 18(3), 296-325.

Giddens, A. (1984). The Constitution of Society: Outline of the Theory of Structuration. Oakland: University of California Press.

Goody, J. (1986). The Logic of Writing and the Organization of Society. Cambridge, UK: Cambridge University Press.

Höög, C., Söderlundh, H., \& Sörlin, M. (2012). Myndigheterna har ordet: Om kommunikation i skrift. Stockholm: Nordstedt.

Höög, C. \& Kvåle, G. (red.) (2018). Evalueringens sakprosa. Seks studier av evaluerende tekster i barnehage og skole. Sakprosa, 10(29). (Temanummer). 
Kjærgaard, A. (2012). Fra lidenskab til ligegyldighed - En caseanalyse fra Danmarks Domstole af et sprogpolitisk projekts (manglende) gennemslagskraft. Sakprosa, 4(1).

Ledin, P. \& Selander, S. (2003). Institution, text och genre. In: Englund, B. og Ledin, P. (red.) (2003). Teoretiska perspektiv på sakprosa, 91-122. Lund: Studentlitteratur.

Luckmann, T. (2009). Observations on the structure and function of communicative genres. Semiotica, 173(1/4), 267-282.

Miller, C. R. (2004). Genre as social action. Quarterly Journal of Speech, 70, 151-167.

Reiff, M. \& Bawarshi, A. (red.). (2016). Genre and the Performance of Publics. Utah: Utah State University Press.

Russell, D. R. (1997). Rethinking Genre in School and Society: An Activity Theory Analysis. Written Communication, 14(4), 504-554.

Schryer (1993). Records as Genre. Written Communication, 10(2), 200-234.

Skärlund, S. (2020). Minskade kostnader och ökad lönsamhet. Hållbarhet och föredömlighet som mål och medel hos svenska företag med statligt ägande. Sakprosa, 12(2).

Smart, G. (2006). Writing the Economy: Activity, Genre and Technology in the World of Banking. London: Equinox Publishing.

Smith, D. E. (1984). Textually mediated social organization. International Social Science Journal, 36(1), 59-75.

Starke-Meyerring, Doreen, Paré, Anthony, Artemeva, Natasha, Horne, Miriam, and Yousoubova, Larissa (red.). (2011). Writing in Knowledge Societies. Perspectives on Writing. WAC Clearinghouse; Parlor Press. (https://wac.colostate.edu/books/perspectives/winks/)

Tønnesson, J. L. (2008). Hva er sakprosa. Oslo: Universitetsforlaget.

Tønnesson, J. L. (2013). Nyere sakprosaforskning i Norge: En kort presentasjon. Nordisk Tidsskrift for Informationsvidenskab og Kulturformidling, 2(39). 
Tønnesson, J. L. \& Berge, K. L. (2009). Forskningen om sakens prosa. Sakprosa, 1(1).

Winsor, D. A. (2000). Ordering Work: Blue-Collar Literacy and the Political Nature of Genre. Written Communication, 17(2), 155-184.

Yates, J. (1989). Control through communication: The rise of system in American management. Baltimore: Johns Hopkins University Press. 